\title{
Article
}

\section{Free Global DEMs and Flood Modelling-A Comparison Analysis for the January 2015 Flooding Event in Mocuba City (Mozambique)}

\author{
Julio Garrote (D)
}

check for updates

Citation: Garrote, J. Free Global DEMs and Flood Modelling-A Comparison Analysis for the January 2015 Flooding Event in Mocuba City (Mozambique). Water 2022, 14, 176. https://doi.org/10.3390/w14020176

Academic Editor: Laurens

M. Bouwer

Received: 22 November 2021

Accepted: 5 January 2022

Published: 10 January 2022

Publisher's Note: MDPI stays neutral with regard to jurisdictional claims in published maps and institutional affiliations.

Copyright: (C) 2022 by the author. Licensee MDPI, Basel, Switzerland. This article is an open access article distributed under the terms and conditions of the Creative Commons Attribution (CC BY) license (https:// creativecommons.org/licenses/by/ $4.0 /)$.
Department of Geodynamics, Stratigraphy, and Palaeontology, Faculty of Geology, Complutense University of Madrid, 28040 Madrid, Spain; juliog@ucm.es; Tel.: +34-913944850

\begin{abstract}
Flood hazard and risk analysis in developing countries is a difficult task due to the absence or scarce availability of flow data and digital elevation models (DEMs) with the necessary quality. Up to eight DEMs (ALOS Palsar, Aster GDEM, Bare Earth DEM, SRTM DEM, Merit DEM, TanDEM$X$ DEM, NASA DEM, and Copernicus DEM) of different data acquisition, spatial resolution, and data processing were used to reconstruct the January 2015 flood event. The systematic flow rate record from the Mocuba city gauge station as well as international aid organisms and field data were used to define both the return period peak flows in years for different flood frequencies $\left(\mathrm{T}_{\text {year }}\right)$ and the January 2015 flooding event peak flow. Both visual and statistical analysis of flow depth values at control point locations give us a measure of the different hydraulic modelling performance. The results related to the Copernicus DEM, both in visual and statistical approach, show a clear improvement over the results of the other free global DEMs. Under the assumption that Copernicus DEM provides the best results, a flood hazard analysis was carried out, its results being in agreement with previous data of the effects of the January 2015 flooding event in the Mocuba District. All these results highlight the step forward that Copernicus DEM represents for flood hazard analysis in developing countries, along with the use of so-called "citizen science" in the form of flooding evidence field data acquisition.
\end{abstract}

Keywords: flood hazard; hydraulic modelling; global DEMs; Copernicus DEM; Mocuba city; Mozambique

\section{Introduction}

Floods, in any of their typologies, are probably the most frequently recurring natural phenomenon affecting global society, regardless of their geographical location or socioeconomic development, as shown by the data collected by the International Disasters Database for the period 1900-2020 [1]. This international database collects 11,356 records of hydrological and meteorological events around the world for the time period between 1900 and 2020, with totals of 8.6 million deaths and 2600 million US dollars (2019) of economic damage. Considering only hydrological events, the totals are of around 7 million people dead and 900 million US dollars (2019) in economic damage. However, those data are only a partial image of reality. Data availability for older events (before the 1950s) and geographic regions (mostly developing countries) are not similar in quality to the most recent events and data from developed countries. All those previous data constitute the main reason why flood risk management is an essential tool from both a social and an economic perspective, the purpose being to reduce flooding losses around the world. To reinforce that idea, we must bear in mind the results of Hallegatte et al. [2], who estimated that global flood losses by 2050 would amount to a total of USD 1 trillion.

Among other main data sources such as peak flow (or flow hydrograph) data or Manning's $n$ value (surface roughness), the availability of appropriate surface topographic data is essential [3] for a correct hydrodynamic modelling and flood hazard assessment. There are multiple studies of the influence of surface topography data (mostly digital 
elevation models-DEMs) in hydrodynamic modelling (e.g., [4-9]), where one of the main conclusions is the positive relationship between higher spatial resolutions and more accurate flooding predictions. The necessity of high-resolution DEMs appears to be essential for urban flooding assessments [10-13], where the effect on buildings is more evident and their inclusion in the DEMs $[11,14]$ is probably the most frequent way to represent those buildings in the two-dimensional (2D) hydrodynamic models needed to simulate the floodwater dynamics in urban areas (e.g., [15-18]).

The above paragraph highlights the necessity of accurate and high spatial resolution topographic data for reliable assessments of flooding area mapping and flood hazard analysis. However, the availability of these DEMs is scarce and mainly confined to developed countries. Thus, this unavailability of high-precision data for hydrodynamic modelling in most cases leads to the use of free global DEMs, which range from 12 to $90 \mathrm{~m}$ in spatial resolution. Usually, the data in free global DEMs include vegetation and buildings, which is not the case of DTMs, in which data represent the "natural" surface of a terrain. The most common technique for creating global DEMs is the airborne and spaceborne Interferometric Synthetic Aperture Radar (InSAR) [19], which is the technology behind the most popular free global DEM, the Shuttle Radar Topography Mission (SRTM). However, most of these global DEMs present a series of more or less systematic errors associated with different factors both in the terrain (mainly vegetation and bodies of water) and in the sensor itself. Those DEM errors were categorized by Wise [20] as systematic, blunders or random, and they derived from different sampling and/or processing errors. In relation to flood modelling, the sources of systematic errors [19] derive from interpolation techniques, erroneous sink filling, hydrological corrections, vegetation, and deficient sampling, which impede the resolution of urban features, as has been pointed out by multiple previous assessments (e.g., [21-28]).

As stated previously, the SRTM is the most commonly used one in data-sparse regions [29,30], and few studies have compared flood extents using different DEMs [12,31,32]. However, the results of different studies [33-35] have shown that SRTM is not the best option and other DEMs, such as the Multi-Error-Removed-Improved-Terrain (MERIT) model, have fewer artefacts and a better performance in flood modelling. Even so, we must not forget that the MERIT model (like other free global DEMs such as Bare Earth DEM, EarthEnv, or Viewfinder Panorama) is fundamentally based on SRTM data. Other available global DEMs not derived (fully or partially) from SRTM are the Alos Palsar DEM, the ASTER GDEM, the TanDEM- $X$, or the Copernicus DEM.

There are multiple previous assessments of flood modelling and flood hazard analysis using free global DEMs in data-sparse regions (e.g., [7,36-39]). Thus, at this point our analysis is not innovative, but in fact it is when, among the models (DEMs) chosen, one takes into account the Copernicus DEM, which (to the present author's knowledge) has not been used in this type of work, probably due to its recent date of distribution. Most of them use the SRTM model as the only data source, and others use it as one of the models analyzed. In general, when more than one free DEM is compared, the SRTM and ASTER DEM are usually selected [40,41]; although, other DEMs have also been used, such as the MERIT, TanDEM-X, or EU-DEM [38,41,42], and they usually show a better performance than SRTM or ASTER. However, although more recent DEMs are improving their performance in hydraulic modelling, the spatial accuracy (both horizontal and vertical) of these models has not yet reached a level of quality that would give the results obtained from them a high degree of reliability. This is especially true in urban areas, where the geometric complexity of the territory is very high, and not so much in rural areas, where previous studies [8] have shown that an increase in spatial resolution below $50 \mathrm{~m}$ does not provide significant improvements in the results.

The errors and weaknesses in global DEMs propagate into hydraulic modelling, and thus condition its results. This will therefore affect flood hazard analysis tasks as well as flood risk management, especially in data-sparse regions. Therefore, the limitations caused by the lack of precision of global DEMs must also affect the results obtained in recent global 
flood-prone area models [43-45], limiting their usefulness mainly to urban environments. These problems are undoubtedly the reason and origin of the calls for attention $[46,47]$ to the need to develop new DEMs on a global scale and with a greater degree of precision in their data.

The main aim of the present work is to assess the performance of eight different free global DEMs for flood modelling and hazard analysis in the urban environment of Mocuba city (Mozambique). The use of up to eight free global DEMs allows us to analyze and compare the performance of most of the available free global DEMs, and rank them on the basis of their capacity to give us reasonable and credible outputs for the main hydrodynamic variables (flow depth and velocity). To achieve this goal, we used the January 2015 flood event, one of the most important flooding events in recent Mozambique history. At first, we used the peak flow record of the Mocuba gauge station for flood frequency analysis, with the aim to relate peak flow values and frequency (return period of flood), and a 500-year return period peak flow was used in a two-dimensional (2D) hydrodynamic model (Iber [48] free software). Due to the underestimation of peak flows associated with different return periods, the peak flow estimated from field data (which is almost three times that associated with the 500-year return period) was also used to carry out a new hydraulic modelling using the different free global DEMs considered. From the results obtained, it can be seen that the MERIT and Copernicus models are the ones that offer the best results, especially the latter, which shows the best results in terms of the extent of the flood zone and its flow depth values. Although the spatial resolution and topographic accuracy of the data are not yet suitable for carrying out analyses of flood hazard and risk on a local scale, the results obtained can be considered for regional analyses and flood risk management, from the perspective of selecting the most dangerous areas in which to prioritize the creation of more detailed studies. What is more, in view of the results obtained with the Copernicus DEM, we can propose its usefulness for hydraulic modelling and flood hazard analysis in scenarios in which the river channel is above $100 \mathrm{~m}$ in width; although more analyses should be carried out using this topographic model in other types of scenarios (vegetation, type of channel...).

\section{Materials and Methods}

\subsection{Study Area}

The city of Mocuba is located in the Zambezia region of Mozambique, about $100 \mathrm{~km}$ inland from the capital of Zambezia Province, the port city of Quelimane. The city of Mocuba has a population of about 70,000 people, but this rises to 230,000 people for the whole district of Mocuba. The city of Mocuba is located on the banks of the Licungo River (Figure 1), just downstream from the confluence of this river with its tributary, the Lugela River. Most of the urban area of Mocuba is located on the right bank of the Licungo River, where a somewhat chaotic urban development can be observed, composed of old buildings from the colonial era (Mozambique was a Portuguese colony until 1975), and other, more modern buildings of poor construction quality. These low-quality, generally single-story buildings are the most common approaching the banks of the Licungo River. For this reason, the vulnerability of the buildings is considerable. Available information [49] for the Mozambique country in general indicates estimated damages of about $75-80 \mathrm{EUR} \mathrm{m}^{-2}$ in rural areas and about $400 \mathrm{EUR} \mathrm{\textrm {m } ^ { - 2 }}$ in urban areas, when a 2-meter flow depth affects buildings. It is clear that these average figures cover very different situations. The same data indicate that for a 2-meter flow depth, the damage factor for buildings (building plus contents) is close to $85 \%$. 

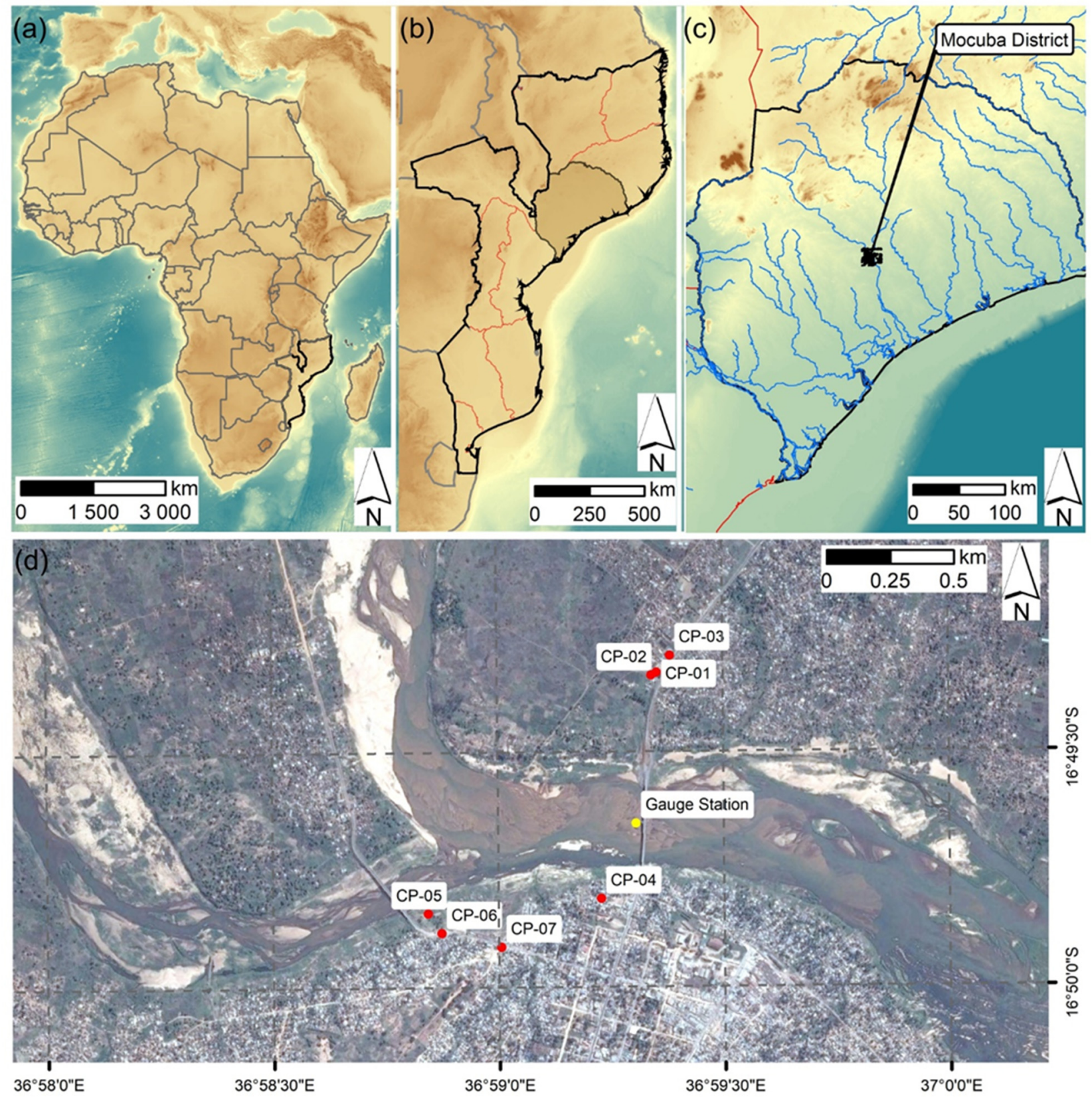

Figure 1. Location map of Mozambique (a), Zambezia Province (b), Mocuba District (c), and Mocuba city (d) with the spatial location of the Mocuba gauge station and field control points (CPs) used in the present flooding assessment. Aerial image (d) from Google Earth ${ }^{\odot}$.

On the other hand, the Licungo River extends over an area of approximately $30,000 \mathrm{~km}^{2}$, entirely within the territory of Mozambique. The headwaters of the river, north of the city of Gurue, are located in the mountainous reliefs whose summit is located in the Namuli Peak (with an altitude of $2419 \mathrm{~m}$ a.s.1), where intense rainfall feeds the flooding process at the mid and lower Licungo River basin. In fact, the location of Mocuba city could be used as the upper limit of flood-prone areas of the Licungo River basin. These intense rainfall events are frequently linked to the activity of cyclone systems in the Pacific Ocean.

These heavy rainfall events have produced at least 10 flooding events in the Mocuba District since the middle of the 20th century, according to information available in the International Disasters Database [1]. Most catastrophic events are dated 1970, 2001, 2013, 2015, and 2019; in the two more recent events, the intense rainfall had its origin in the 
coalescence of two Pacific cyclones at the same time (the Chezda and Bansi cyclones in 2015, and the Idai and Kenneth cyclones in 2019).

\subsection{The January 2015 Heavy Rainfall and Flooding Event}

According to the Dutch Risk Reduction Team Report [50], the 2015 flooding event lasted for approximately one month in the Licungo lower basin, beginning on 11 January 2015 and reaching its peak on 12, when the waters reached a depth of more than $12 \mathrm{~m}$ at the Mocuba gauging station and one of the bridges over the Licungo River collapsed. In Mocuba, the water levels dropped from 13 to 16 January 2015.

The flooding event was fed by an intense rainfall (with up to $590 \mathrm{~mm}$ [51] over the month of January recorded in Mocuba, although other sources [50] put the figure as high as $700 \mathrm{~mm}$ ), which was related to a 30-year return period [51], and rainfall intensity on 11 January 2015 was above $60 \mathrm{~mm} \mathrm{~h}^{-1}$ [50] according to Meteosat data. Considering that all the rainfall over the Licungo River basin contributed to the river discharge in Mocuba, the maximum peak flow estimations range from 13,000 to $19,000 \mathrm{~m}^{3} \mathrm{~s}^{-1}$; much higher than the estimation of the Directorate National of Water from the gauge station rating curve (about $6500 \mathrm{~m}^{3} \mathrm{~s}^{-1}$ ) [51].

As a consequence of this extreme natural event, the damage for the whole area affected in the provinces of Zambezia and Nampula (Mozambique) was around USD 371 million (2.4\% of the national GDP) [51]., while the tasks of early recovery, post-disaster recovery, and vulnerability reduction were estimated at a total amount of USD 490 million. The postevent operations of emergency and recovery carried out by the International Federation of Red Cross and Red Crescent Societies helped 1588 households and 7940 people [52] in the Mocuba District. According [51] to the National Institute for the Management of Natural Disasters of Mozambique, registered casualties amounted to a total of 155, 10 of which took place in the city of Mocuba.

\subsection{Hydro-Meteorological Data}

Peak flow data were available for Mocuba city due to the presence of a gauge station with a non-continuous record from 1943 to 2014. The record of annual maximum peak flow derived from gauge station data is 69 years long, although personal communication from Mozambican technicians highlights a limited trust in higher peak flow values, due to deficiencies in gauging station measurements at times when flows rates are very high.

Assuming these measurement limitations, three extreme distribution values (Gumbel, generalized extreme values (GEV), and two-component extreme values (TCEV)) were fitted by the maximum likelihood (ML) method to obtain the relationship between peak flow rate and T-year return periods (Table 1). Further, two-flow frequency analyses (FFA) were carried out considering the January 2015 peak flow (of which the value was estimated by field data [51]) as non-systematic data, first as exact censored data $\left(18,000 \mathrm{~m}^{3} \mathrm{~s}^{-1}\right)$, and second as censored data (range or double limit data-13,000 to $18,000 \mathrm{~m}^{3} \mathrm{~s}^{-1}$ ).

The field data campaign after the January 2015 flooding event, accompanied by Mozambican technicians from the "Universidade Pedagógica de Mozambique", in Mocuba city, allowed us to obtain the topographic data of seven control points linked to buildings affected or not affected by the flooding event. In the case of affected buildings, flow depth height data were collected. 
Table 1. Flow frequency analysis (FFA) from systematic and non-systematic data in Mocuba city (Mozambique).

\begin{tabular}{cccccccccc}
\hline \multirow{2}{*}{\begin{tabular}{c}
\multirow{2}{*}{$\begin{array}{c}\text { Return Period } \\
\text { (Years) }\end{array}$} \\
\cline { 2 - 9 }
\end{tabular}} & \multicolumn{3}{c}{ Systematic Data } & \multicolumn{3}{c}{ Non-Systematic Data } \\
\cline { 2 - 9 } & Gumbel & GEV & TCEV & Gumbel & GEV & TCEV & Gumbel & GEV & TCEV \\
\hline 5 & 2671.8 & 2674.0 & 2700.7 & 2964.7 & 2879.5 & 2673.8 & 2884.7 & 2857.9 & 2694.4 \\
10 & 3273.5 & 3428.7 & 3410.7 & 3674.3 & 3901.5 & 3472.8 & 3571.6 & 3847.7 & 3554.7 \\
25 & 4033.7 & 4517.9 & 4441.8 & 4570.9 & 5555.3 & 5269.8 & 4439.6 & 5429.5 & 5508.1 \\
50 & 4597.7 & 5436.8 & 5338.2 & 5236.0 & 7111.7 & 8000.0 & 5083.6 & 6900.6 & 7889.0 \\
100 & 5157.5 & 6454.4 & 6323.8 & 5896.2 & 9004.5 & $11,095.2$ & 5722.7 & 8671.7 & $10,416.0$ \\
500 & 6451.2 & 9277.1 & 8830.1 & 7421.9 & $15,164.6$ & $18,224.1$ & 7199.8 & $14,335.9$ & $16,241.5$ \\
1.000 & 7007.3 & $10,727.0$ & 9915.7 & 8077.8 & $18,837.0$ & $21,189.3$ & 7834.8 & $17,659.2$ & $18,665.6$ \\
5.000 & 8298.1 & $14,764.1$ & $12,402.6$ & 9600.1 & $30,826.8$ & $27,869.1$ & 9308.6 & $28,321.9$ & $24,182.5$ \\
10.000 & 8853.7 & $16,839.4$ & $13,364.6$ & $10,255.3$ & $37,978.4$ & $30,065.2$ & 9942.9 & $34,581.2$ & $26,021.2$ \\
\hline
\end{tabular}

\subsection{Surface Terrain Data-Global DEMs}

Several free global DEMs have been used to carry out a comparison regarding the performance of hydrodynamic simulations for flood-prone area delimitations and hazard analyses in sparse-data regions. An overview of selected free global DEMs, and their main features are given in Table 2. In summary, their original spatial resolution is between 30 and $90 \mathrm{~m}$, and they have been generated either from optical sensors (as is the case of ALOS and ASTER DEM) or by InSAR techniques (as is the case of SRTM, TanDEM-X, or Copernicus DEM).

Table 2. Overview of free global DEMs used for peak flow modelling in Mocuba city (Mozambique).

\begin{tabular}{|c|c|c|c|c|}
\hline DEM Dataset & Sensor/Satellite & Resolution (m) & Vertical Accuracy & Reference \\
\hline ALOS PALSAR & Optical & 12,30 & $4.4 \mathrm{~m}$ (RMSE) & Tadono et al. [53] \\
\hline ASTER GDEM & Optical & 30 & $17 \mathrm{~m}(95 \%$ conf. $)$ & Meyer et al. [54] \\
\hline Bare Earth DEM & SRTM & 90 & 5.9 m (RMSE) & O'Loughlin et al. [55] \\
\hline SRTM & SAR C Band & 30,90 & $6 \mathrm{~m}(\mathrm{MAE})$ & Farr et al. [26] \\
\hline MERIT & $\begin{array}{c}\text { ALOS, SRTM, and } \\
\text { Viewfinder Panorama }\end{array}$ & 90 & $5 \mathrm{~m}$ (LE90) & Yamazaki et al. [33] \\
\hline TanDEM-X & SAR X Band & 30,90 & $1.93 \mathrm{~m}$ (LE90) & Wessel et al. [56] \\
\hline NASADEM & SAR C Band & 30 & $5.3 \mathrm{~m}$ (RMSE for USA) & Buckley et al. [57] \\
\hline Copernicus DEM & SAR X Band & 30 & $<4$ m (LE90) & $\begin{array}{l}\text { Airbus Defence and } \\
\text { Space GmbH [58] }\end{array}$ \\
\hline
\end{tabular}

Two of these are the main sources of data of the currently most used free global DEMs: First the SRTM, from which other DEMs are derived, such as the Bare Earth DEM (BEST DEM, O'Loughlin et al. [55]), which involves removing the vegetation artefacts present in the original SRTM DEM; the MERIT DEM, in which errors are reduced by removing absolute bias, stripe noise, speckle noise, and vegetation bias (Yamazaki et al. [33]); or the NASA DEM (Buckley et al. [57]), which has been developed by completely reprocessing the SRTM radar data and then merging it with refined ASTER GDEM elevations. The second main data source is the TanDEM-X [59], from which the recent Copernicus DEM [58] derives, by terrain (spikes, voids, noise, and negative elevation) and hydrological (oceans, lakes, rivers, islands, or bridges) editing.

The group of free global DEMs used for hydrodynamic modelling in the city of Mocuba is used in the format in which they can be downloaded from their respective file servers (Appendix A). The only processing of the data, with the aim of obtaining a homogeneous 3D mesh in the Iber software, consisted in resampling the data to a similar spatial resolution. The ESRI ArcGIS 10.6 environment was used for the process of resampling, and a value of $10 \mathrm{~m}$ was selected as the common spatial resolution of all DEMs. 
Most of the DEMs used can be considered digital surface models (DSM), in which vegetation, buildings, water bodies, etc. are included. These DSM characteristics mean that they should only be used with caution in flood models [19]. As pointed out by Archer et al. [37], the processing and filtering of original data can produce an improvement in free global DEMs. However, for this assessment the DEMs have been used without any processing or filtering (except for those where the original downloaded data were already subjected to these treatments). This was done in this way with the idea of trying to replicate the analyses that could be carried out by public authorities responsible for flood risk management in developing countries, as these are likely to be the most frequent users of this type of DEM. In more economically developed countries, the analysis is likely to be carried out using higher spatial resolution topographic information, mainly LiDAR data. Therefore, we understand that end users in these developing countries will not carry out the complex tasks of processing and filtering the original topographic information, but will use the data as obtained from the web servers.

\subsection{Mocuba City Urban Data}

The urban Mocuba city building footprint at vector format was obtained from the OpenStreetMap [60] dataset. The OpenStreetMap (OSM) is a geographic database with a worldwide coverage, which is constantly growing and ensures regular updates in terms of the accuracy and completeness of the data, so nowadays it is considered reliable [61,62]. The OSM has been previously used for flood vulnerability analysis [63] with good results, since it does not solve all the problems linked to the vulnerability of buildings due to their shape and constitution, but data are consistent and openly accessible, which makes it easier and more cost effective to transfer vulnerability models to other regions. Although the OSM database does not include data about inhabitants per building, it can be a good approach (and probably the best public available data for Mocuba city), both regarding the number of buildings in the flood-prone area and the number of buildings within different building stability hazard areas.

\subsection{Methodological Approach}

The methodological approach of the present assessment could be divided into three main groups. The first group includes the use of available hydro-meteorological data (annual peak flow series) for FFA, with the aim of defining the peak flow value related to different return periods. The results of this FFA allow us to determine the frequency of different peak flow magnitudes.

Those peak flows for the T-year return period were used for hydrodynamic modelling with the free global DEMs (the second main group of working tasks) under consideration, so lower and higher peak flows allow one to compare the shape and extension of floodprone areas. For a peak flow value, the hydrodynamic models are similar except for the topographic data, so the differences in results can be related to this variable rather than the combined effect of a group of variables.

Finally, the third main group of working tasks includes those analysis for a calibration of the results obtained with the different hydrodynamic models, based on their comparison with the available field data (Figure 2), as well as with the rating curve of the gauging station located in the city of Mocuba. Furthermore, we selected the best option between the different hydrodynamic models for flood hazard assessment by defining the areas and number of buildings where the hazard level of human loss of stability due to flooding characteristics is high, according to the model of Russo et al. [64]. 

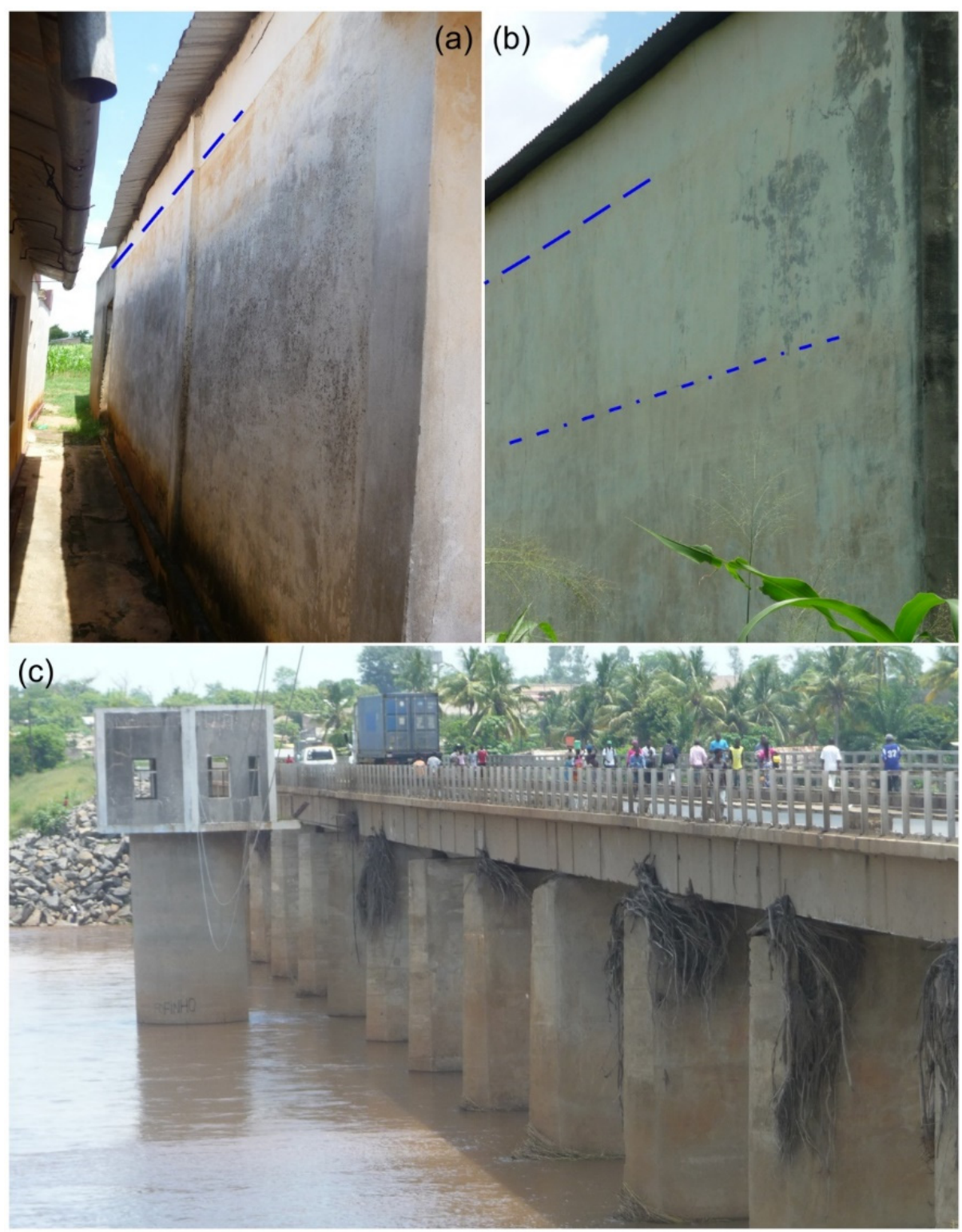

Figure 2. Field data evidence of January 2015 flooding event: palaeostage indicators for CP-01 (a) and CP-05 (b), where blue dashed lines show the water level (flood marks) at these points; Mocuba gauge station and bridge with palaeostage indicators (driftwood) (c).

\section{Results}

\subsection{Flood Frequency Analysis of the Annual Maximum Peak Flow Value Record}

The results of the FFA (Table 1) show significant differences when using only systematic data or systematic and non-systematic data; especially for high return periods (Figure 3) and GEV and TCEV distributions. These results highlight the importance of working with representative data records, which include events of high magnitude. Thus, the absence of these high magnitude events (collected as systematic or non-systematic data) causes an underestimation of the magnitude of the process (in this case, a river flood) with respect to its relative frequency of occurrence. 

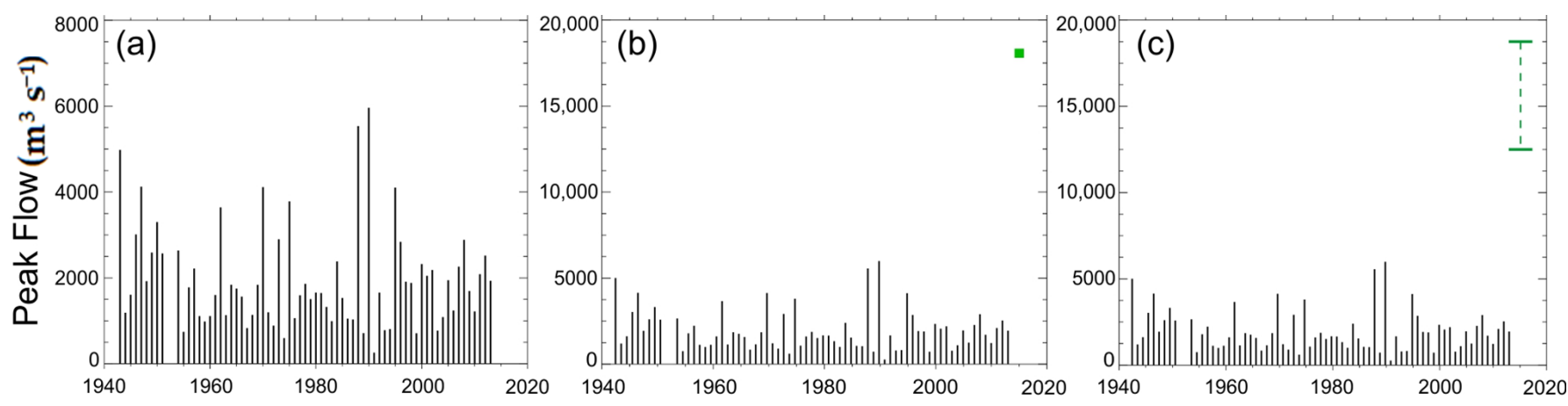

Time (Years)
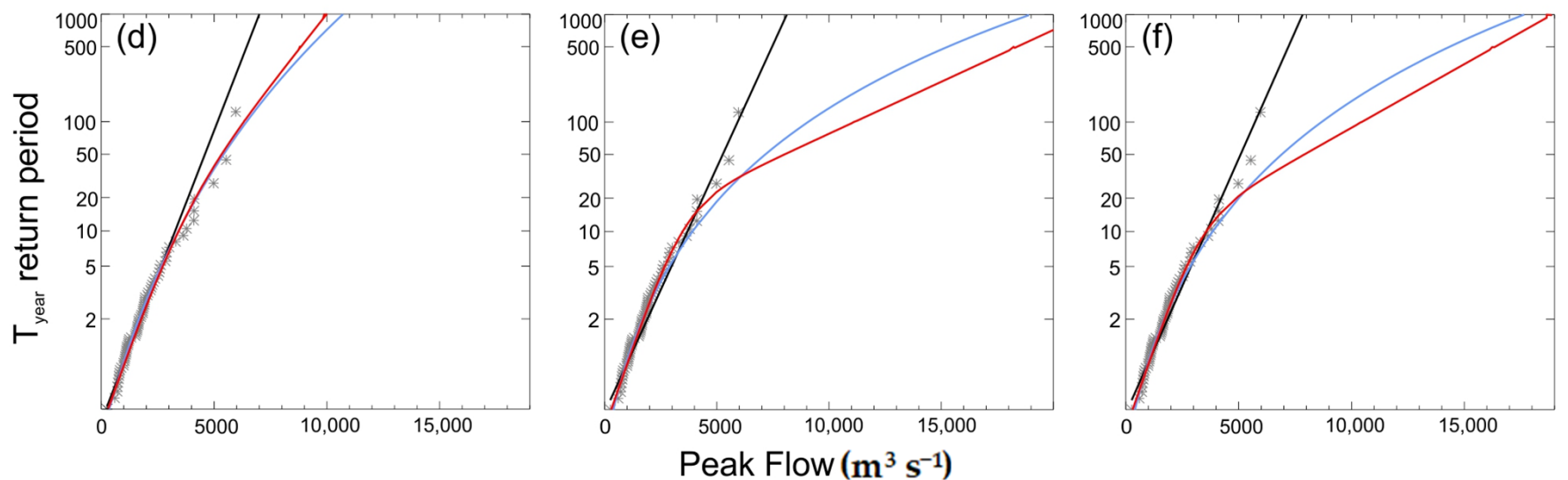

Figure 3. Results for flood frequency analysis (FFAs) in Mocuba city by using only a systematic flow data record $(\mathbf{a}, \mathbf{d})$, systematic and non-systematic data as censored data $(\mathbf{b}, \mathbf{e})$, or range data $(\mathbf{c}, \mathbf{f})$. Peak flow record distribution is shown in $(\mathbf{a}-\mathbf{c})$. The Gumbel (black line), GEV (blue line) and TCEV (red line) distribution results are shown in (d-f). The green dot (b) and dashed line (c) show the use of non-systematic data related to the January 2015 flooding event.

From the first FFA (only systematic data), a 500-year return period peak flow value of $6451 \mathrm{~m}^{3} \mathrm{~s}^{-1}$ is obtained using Gumbel distribution, which is closed to the peak flow reported by the Mozambique Directorate National of Water [51]. However, from the rating curve of the gauge station, the 500-year return period peak flow could be associated with a 9.5-meter flow depth value, far from the $12 \mathrm{~m}$ of flow depth obtained from field data for the January 2015 flood event [51]. When using GEV or TCEV distributions, the peak flow value for the 500-year return period is increased up to values of 9277 and $8830 \mathrm{~m}^{3} \mathrm{~s}^{-1}$. Those peak flow values can be related to flow depth values of about 10.75 and $10.6 \mathrm{~m}$, which are still lower than the field data value for the January 2015 flood event. Furthermore, although the January 2015 flooding event is regarded as probably the most catastrophic event in the recent history of Mozambique, other catastrophic events were dated in 1970, 2001, 2013, and 2019, so the frequency of catastrophic events is not too lower than a 200- or 500-year return period. Higher peak flow estimations [51] shall be related to a T-year return period of up to 10,000 years or more, which may be considered an unrealistic estimate.

When non-systematic data are taken into consideration in the FFA, peak flow values for low-frequency events are significantly increased. This effect is mainly observed for FFAs carried out using the GEV or TCEV distribution functions, as these functions have a higher curvature capacity to adapt to sharper increases of the peak flow value with respect to its frequency. Thus, the peak flow value estimated by the Mozambique National Directorate of Water may be associated with a T-year return period lower than 50 years (a return period of about 35 years). Against this, a peak flow estimation ranging from 13,000 to $18,000 \mathrm{~m}^{3} \mathrm{~s}^{-1}$ [52] is related to a T-year return period higher than 10,000 years using the Gumbel distribution, while, when GEV or TCEV distributions are used, that peak flow is related to a 500- or 1000-year return period. This difference points towards the effect 
of the use of different distribution functions, and the necessary knowledge of rainfall or flow characteristics at the study site.

From Figure 3, we can observe that Gumbel distribution probably underestimates peak flow values for higher return periods, while GEV and TCEV distribution show more similar values. The underestimation associated to the Gumbel distribution function has been highlighted previously $[65,66]$, and it is not a new feature of this study. It can also be noted that the use of estimated field peak flow for the January 2015 event as non-systematic data provide different results depending on how these data are considered. When the January 2015 data are used as exact values, the peak flow values linked to higher return periods are greater than those values when the January 2015 peak flow is used as a range value. In this case, and due to the uncertainty in the field estimation of the January 2015 peak flow, the use of this value as a range could be the more realistic option.

\subsection{Free Global DEMs and Hydrodynamic Modelling}

The comparison of results from all free global DEMs used is going to be made for three different flow rates: one related to high-frequency flow rates (10-year return period); another related to medium-to-low-frequency flow rates (about 100-year to 500-year return periods, depending on the distribution function considered); and finally an extreme event such as the January 2015 flood, with an estimated peak flow of $18,000 \mathrm{~m}^{3} \mathrm{~s}^{-1}$ [51].

For each of these three sets of results, the shape of the flood-prone area, its spatial continuity and the range of values, as well as the values of the slope of the water surface and its spatial distribution were analyzed. The latter analysis was carried out with the aim of determining the presence of peaks and sinks in the DEMs, and on the assumption that the water surface should have a low slope (approximately similar to the slope of the channel) with a reduced spatial variability.

For the results related to the 10-year return period peak flow (Figure 4), two main groups of results can be established on the basis of their visual appearance and spatial continuity. The first group may include the ASTER, NASADEM, ALOS Palsar, and SRTM30, which show high variability in flow depth values for neighboring or adjacent pixels, a lower spatial continuity, and all of them show an artificial appearance surface in the vicinity of Mocuba city. On the other hand, the BEST, Copernicus, MERIT, and TANDEM-X models show a lower variability in flow depth values for neighboring or adjacent pixels, and a higher spatial continuity. From the second group, the BEST and MERIT models show some artificial features like little channels in the flooding area, which change their flow direction at 90-degree angles, possibly conditioned by the height distribution in the pixels.

The previously defined DEM groups are supported by maximum flow depth values too. Thus, the group including ASTER, NASADEM, ALOS Palsar, and SRTM30 DEMs shows flow depth values of up to $30 \mathrm{~m}$ or more ( $36.5 \mathrm{~m}$ for the ASTER DEM), while the second group (the BEST, Copernicus, MERIT, and TANDEM-X models) shows flow depth values ranging from the $13.5 \mathrm{~m}$ of Copernicus DEM to $21.5 \mathrm{~m}$ for the TanDEM-X. The previous maximum values are related to the January 2015 peak flow, just when the flow depth differences between two groups are at their lowest. This effect could be explained by the fact that the maximum values of flow depth in the first group are associated with the presence of artificial depressions within the DEMs, which are the origin of the presence of such high values of flow depth.

When considering the results related to the 100- to 500-year return periods (Figure 5), the description of results is very similar to the previous one. The same two main groups can be established, and the same models are included in each group. Of course, the flood-prone areas are larger than those related to the 10-year return period and the spatial continuity is also greater for all models. When observing the results of the January 2015 peak flow models, the same conclusions are observed, so the BEST, Copernicus, MERIT, and TANDEM-X models show the better performance. From all models, the Copernicus DEM probably shows the most realistic results (Figure 6), where flow depth variations in the channel appear to be related to the presence of sand bars, rocky outcrops, and inner 
channels. Although BEST, MERIT, and TanDEM-X models show a good performance too, the flow depth variations observed in the results are not too easily related to inside channel forms and deposits.

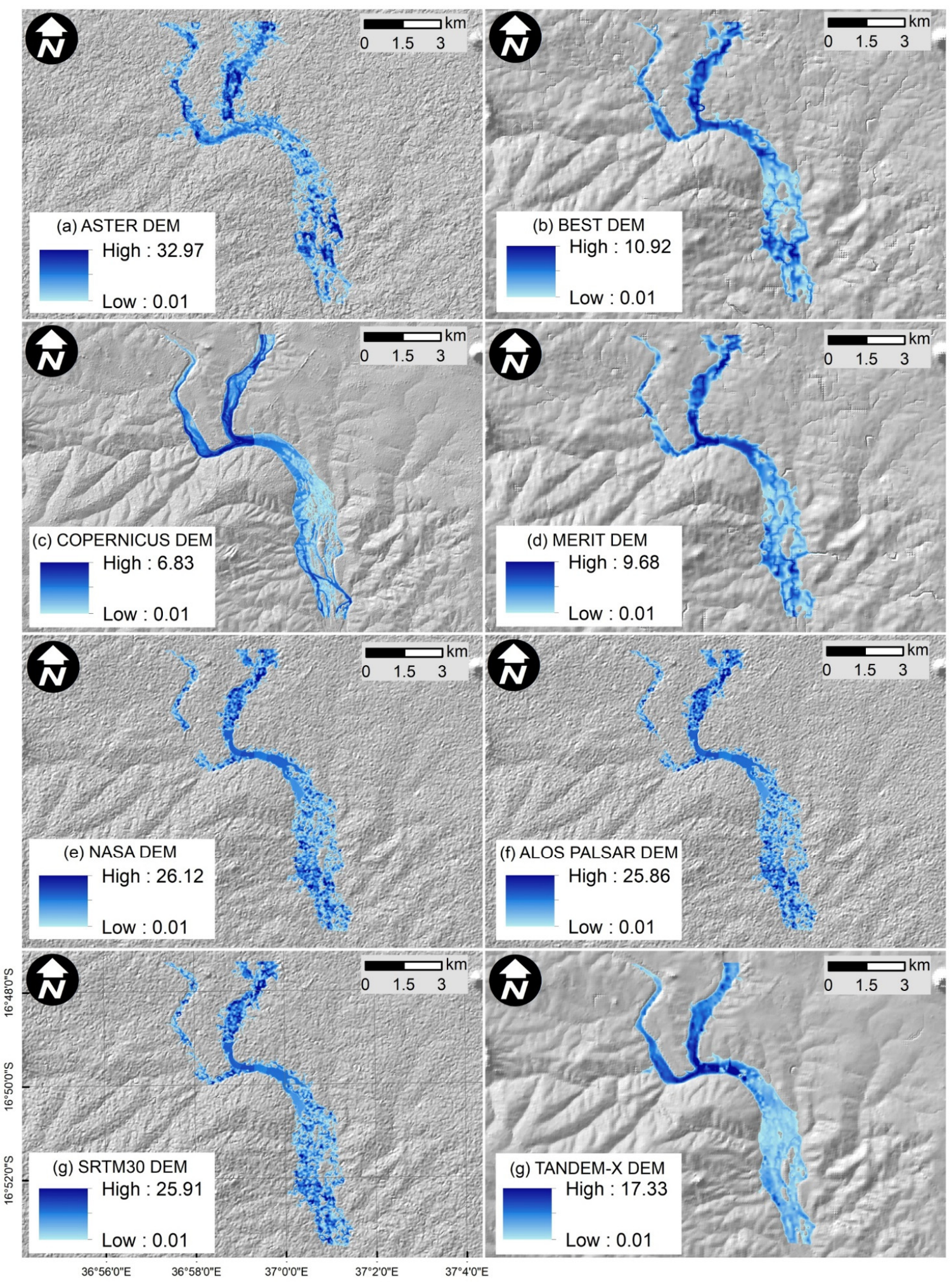

Figure 4. Flow depth results for the 10-years return period peak flow and each one of the free global DEMs used. The effect of noise errors on both the terrain surface and flow depth values $(\mathbf{a}, \mathbf{e}-\mathbf{g})$. 


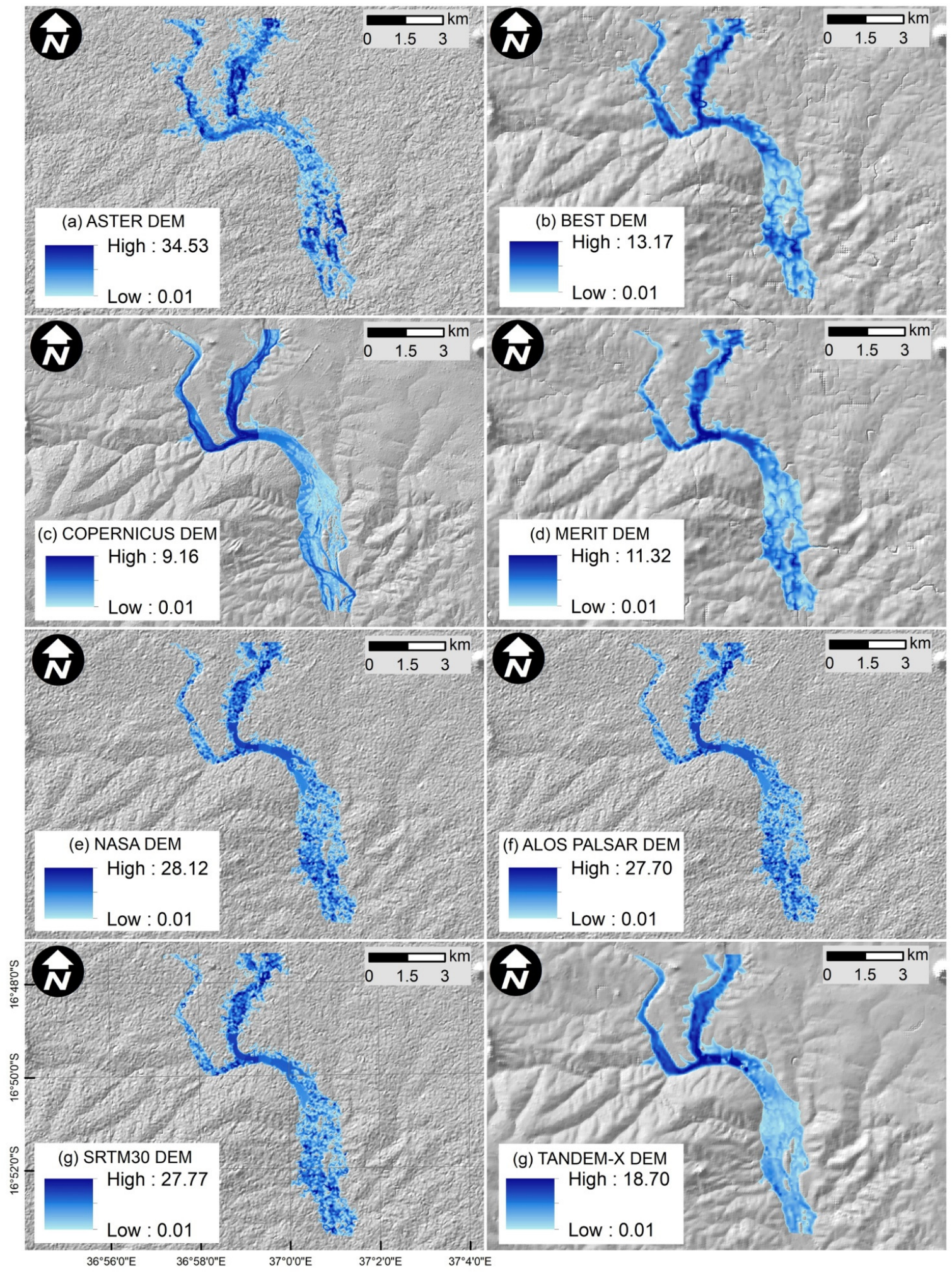

Figure 5. Flow depth results for the 500-year return period peak flow and each one of the free global DEMs used.

The results of water surface slope maps look quite similar to those of the flow depth, but some differences can be pointed out. On the one hand, the high variability in the spatial distribution of slope values can be observed too for the first group of DEMs (ASTER, NASADEM, ALOS Palsar, and SRTM30 DEMs), and they do not show a clear spatial pattern, and the slope variability is clearly lower for the second group of DEMs. This trend 
of high spatial variability cannot be interpreted as a succession of riffles and pools in the river channel, but rather resembles a network of pools as previously noted [6] in the case of the SRTM model.

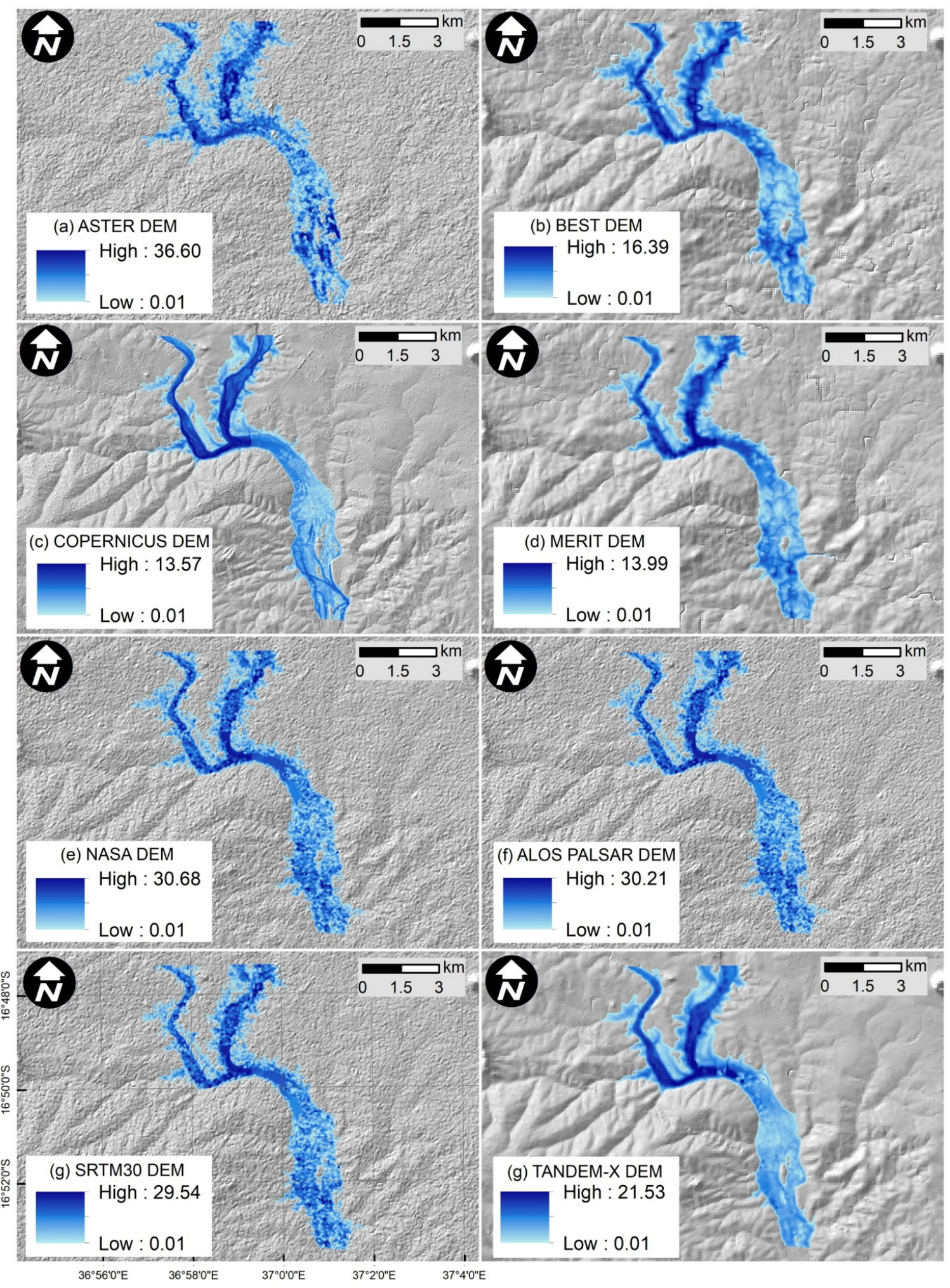

Figure 6. Flow depth results for the January 2015 flooding event in each one of the free global DEMs used, where the peak flow data used $\left(18,000 \mathrm{~m}^{3} \mathrm{~s}^{-1}\right)$ comes from previous reports [52]. 
In the other hand, all DEMs derived from SRTM data (SRTM30, BEST, MERIT, and NASADEM; the ALOS Palsar DEM) show a homogeneous and low slope area just in front of Mocuba city (Figure 7), which corresponds to a flat surface observed in DEMs (which may be due to radar shadows). This "non-natural" feature in water surface slope maps is partially blurred in BEST and MERIT DEMs, those in which filters were applied by developers to remove vegetation and noise.

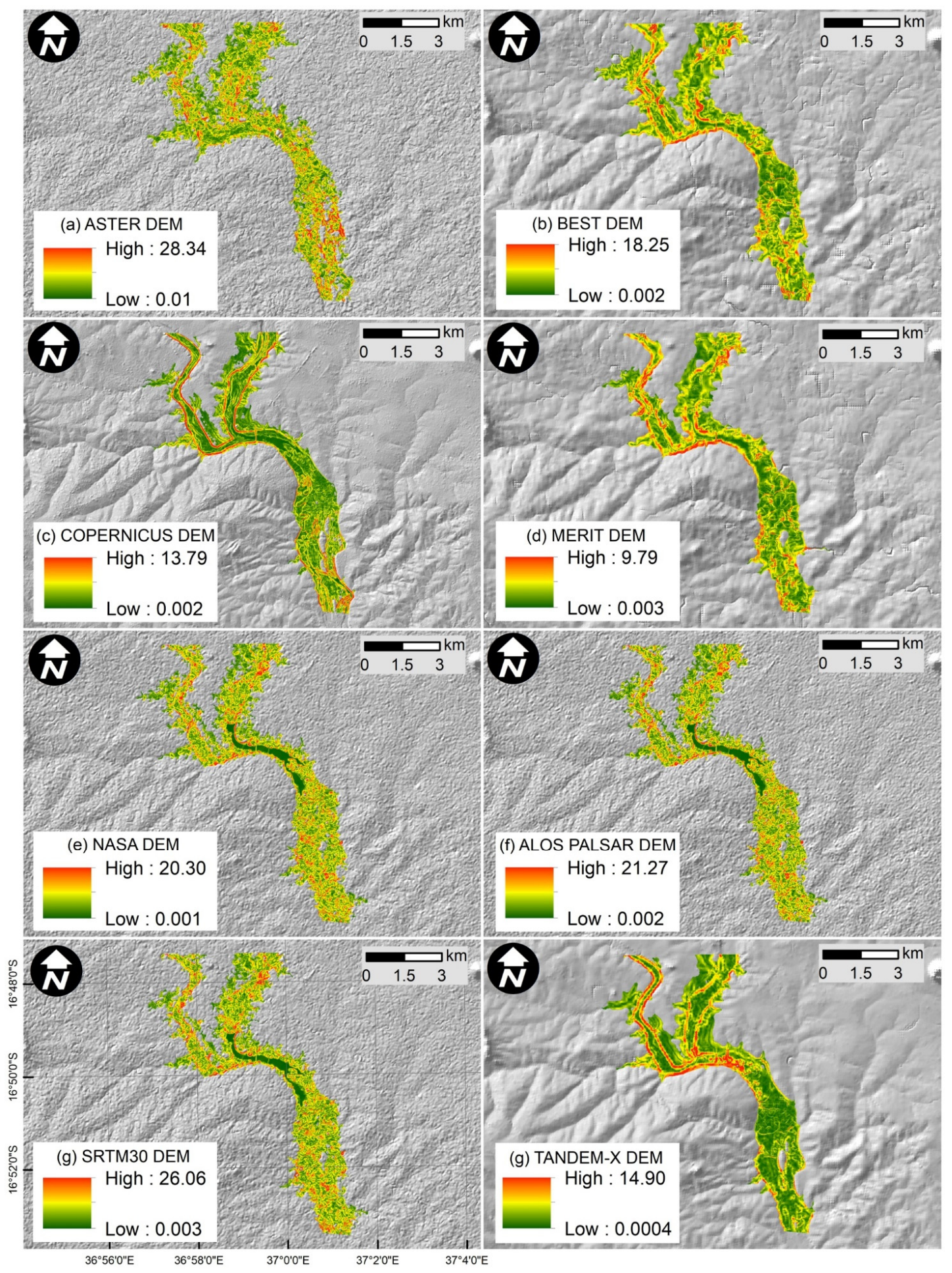

Figure 7. Water surface slope results for the January 2015 flooding event in each one of the free global DEMs used, where the peak flow data used $\left(18,000 \mathrm{~m}^{3} \mathrm{~s}^{-1}\right)$ comes from previous reports [52]. 


\subsection{Comparison of Hydrodynamic Model Results and Field Data}

The comparison of hydrodynamic model results against field data was driven in two ways. First, the flow depth values of each hydrodynamic model (including all DEMs and T-year return periods) were plotted against the Mocuba gauge station rating curve with the aim to highlight deviations from the rating curve and select the best option of free global DEM. The second time, the flow depth results from each combination of "DEM-T-year return period" were compared to the flow depth values of the seven control points collected in the field work after the flooding event. Those seven control points include three water heights measured from building watermarks, and four non-flooding points on both sides of the Licungo River, so they allow one to define the spatial extension of flooding at the January 2015 event.

The two analyses were carried out using the mean absolute error (MAE) and the Nash-Sutcliffe efficiency (NSE) statistical indexes, as shown in Equations (1) and (2).

$$
\mathrm{MAE}=\frac{\sum_{\mathrm{i}=1}^{\mathrm{n}}\left|\mathrm{H}_{\mathrm{L}}-\mathrm{H}_{\mathrm{r}}\right|}{\mathrm{n}_{\mathrm{c}}}
$$

where $\mathrm{H}_{\mathrm{L}}$ is the flow depth of the ith cell for the "modelled scenario", $\mathrm{H}_{\mathrm{r}}$ is the flow depth of the ith cell for the "observed scenario", and $\mathrm{n}_{\mathrm{c}}$ is the number of cells used for the analysis.

$$
\text { MSE }=1-\frac{\sum_{\mathrm{i}=1}^{\mathrm{n}}\left(\mathrm{D}_{\mathrm{m}}-\mathrm{D}_{\mathrm{o}}\right)^{2}}{\sum_{\mathrm{i}=1}^{\mathrm{n}}\left(\mathrm{D}_{\mathrm{m}}-\overline{\mathrm{D}}_{\mathrm{o}}\right)^{2}}
$$

where $D_{m}$ is the flow depth value of the modelled scenario, $D_{o}$ is the flow depth value in the observed scenario, and $\bar{D}_{\mathrm{o}}$ is the mean flow depth value for the observed scenario.

The results obtained for the gauge station and control points are shown in Table 3. In both cases, the results linked to Copernicus DEM are the best option and they show the closest values to the Mocuba gauge station rating curve and the palaeostage indicator (PSIs) marks. For the first analysis, which plots flow depth values (from all free global DEMs) against the gauge station rating curve, the ASTER and TanDEM-X DEMs show the worst results and the other DEMs show MAE values ranging from 0.21 (Copernicus DEM) to 0.38. A similar trend is observed for NSE index, with the best result (0.75) linked to the Copernicus DEM. These results highlight the Copernicus DEM as the best model to reproduce the behavior of the waters (flow depth) within the Licungo riverbed. The error of $0.21 \mathrm{~m}$ shown by the MAE index is quite homogeneous regardless of the return period considered and shows an efficiency of 75\% (NSE value) in reproducing the behavior of the rating curve of the gauging station.

Table 3. Statistical results of the MAE and NSE index comparing hydrodynamic modelling and field data.

\begin{tabular}{ccccc}
\hline & \multicolumn{2}{c}{ Gauge Station } & \multicolumn{2}{c}{ Control Points } \\
\cline { 2 - 5 } & MAE & NSE & MAE & NSE \\
\hline ASTER DEM & 6.46 & -152.29 & 3.23 & -5.23 \\
\hline BEST DEM & 0.25 & 0.67 & 1.79 & -1.10 \\
\hline Copernicus DEM & $\mathbf{0 . 2 1}$ & $\mathbf{0 . 7 5}$ & $\mathbf{0 . 4 4}$ & $\mathbf{0 . 8 1}$ \\
\hline MERIT DEM & 0.32 & 0.46 & 0.56 & 0.73 \\
\hline NASA DEM & 0.38 & 0.26 & 1.42 & -0.23 \\
\hline ALOS Palsar DEM & 0.32 & 0.45 & 1.55 & -0.35 \\
\hline SRTM DEM & 0.29 & 0.54 & 1.56 & -0.62 \\
\hline TanDEM-X DEM & 3.28 & -38.39 & 0.54 & 0.74 \\
\hline
\end{tabular}


The second analysis plots flow depth values against several control points, which include both 2015 flooding and unflooded areas. The results linked to ASTER DEM are the worst once again, but TanDEM-X DEM is now the second best option after the Copernicus DEM and very similar in results to the MERIT DEM. The Copernicus DEM is the only one in which the flow depth values in all the selected non-flooding control points were equal to $0.00 \mathrm{~m}$. The MAE index for the Copernicus DEM shows a mean deviation of $0.44 \mathrm{~m}$ from field data and an efficiency of $81 \%$ (NSE index) reproducing real flow depth values. As the flow depth values in the non-flooding areas are reproduced exactly by the Copernicus DEM model, it is clear that the error at the control points in the flooded areas is higher. This could indicate that the peak flow value associated with the January 2015 event could be even higher than previously estimated.

None of the other models show a uniform trend in the relationship between modelled and real flow depth values. Thus, in the rest of the models, we can observe control points in which the modelled flow depth value is greater than the one observed, while in other control points the relationship is inverse. Thus, this heterogeneity in the results cannot be related to the peak flow value, but to possible errors in DEMs and their deficient topographic surface representativeness.

The MERIT and TanDEM-X models offer the best results after the Copernicus model. The results for both models are similar, and slightly better in the MERIT model. This is in agreement with previous reports by Archer et al. [37], who already indicated that the TanDEM-X model (in its non-free access model, with a higher spatial resolution of $12 \mathrm{~m}$ ), without additional surface artefact processing, improved on the performance of the SRTM model but not on the MERIT model in flood estimation.

\subsection{Flood Hazard Assessment in Mocuba City}

The hydraulic model developed upon the Copernicus DEM, which showed the best results in the previous section, was used to define the dragging people hazard zone according to the Russo et al. [64] model. The flood hazard model uses the flow depth and flow velocity variables to define up to five different hazard levels (from low hazard for adults and children-value 1, to extreme hazard for adults-value 5). In the absence of building scale census data (including inhabitants per building), the analysis was carried out at building scale by using data from the OpenStreetMap database [60].

The results (Figure 8a) from hydraulic modelling show that a total of 2113 buildings in Mocuba city were affected during the January 2015 flooding event (using an estimated peak flow of $18,000 \mathrm{~m}^{3} \mathrm{~s}^{-1}$ ). This value is greater than the number of households (1588) helped by the International Federation of Red Cross and Red Crescent Societies [52] in the Mocuba District, but it is very close to the number of buildings (1452) where flood hazards are moderate to extreme. From the flood hazard analysis, attention must be paid to the high number of buildings (Figure $8 \mathrm{~b}$ ) where the hazard level is extreme (1422), which highlights the magnitude of the January 2015 flooding event and its associated high flood risk.

Other damage models are focused on building stability or damage rate in relation to both flow depth and velocity variables. The Pistrika and Jonkman model [67], where

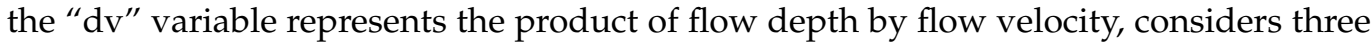
damage levels and it was used in Mocuba city.

- $\mathrm{dv}<3 \mathrm{~m}^{2} \mathrm{~s}^{-1}$ yields only "inundation damage";

- $\quad 3 \mathrm{~m}^{2} \mathrm{~s}^{-1} \leq \mathrm{dv}<7 \mathrm{~m}^{2} \mathrm{~s}^{-1} 1$ yields "partial damage";

- $\mathrm{dv} \geq 7 \mathrm{~m}^{2} \mathrm{~s}^{-1}$ yields "total destruction".

The results from the Pistrika-Jonkman model show that the majority of buildings are affected by "flood damage" hazard level (1814 buildings of the 2113 affected by the January 2015 flooding event). Only 82 buildings show a "total destruction" damage level (Figure 8c), but these data cannot be compared to other data sources, such as the International Federation of Red Cross and Red Crescent Societies [52] report. Neither the report [52] nor the field data point to the occurrence of buildings collapsing, due to the absence of any commentary in the report or by the inhabitants. 


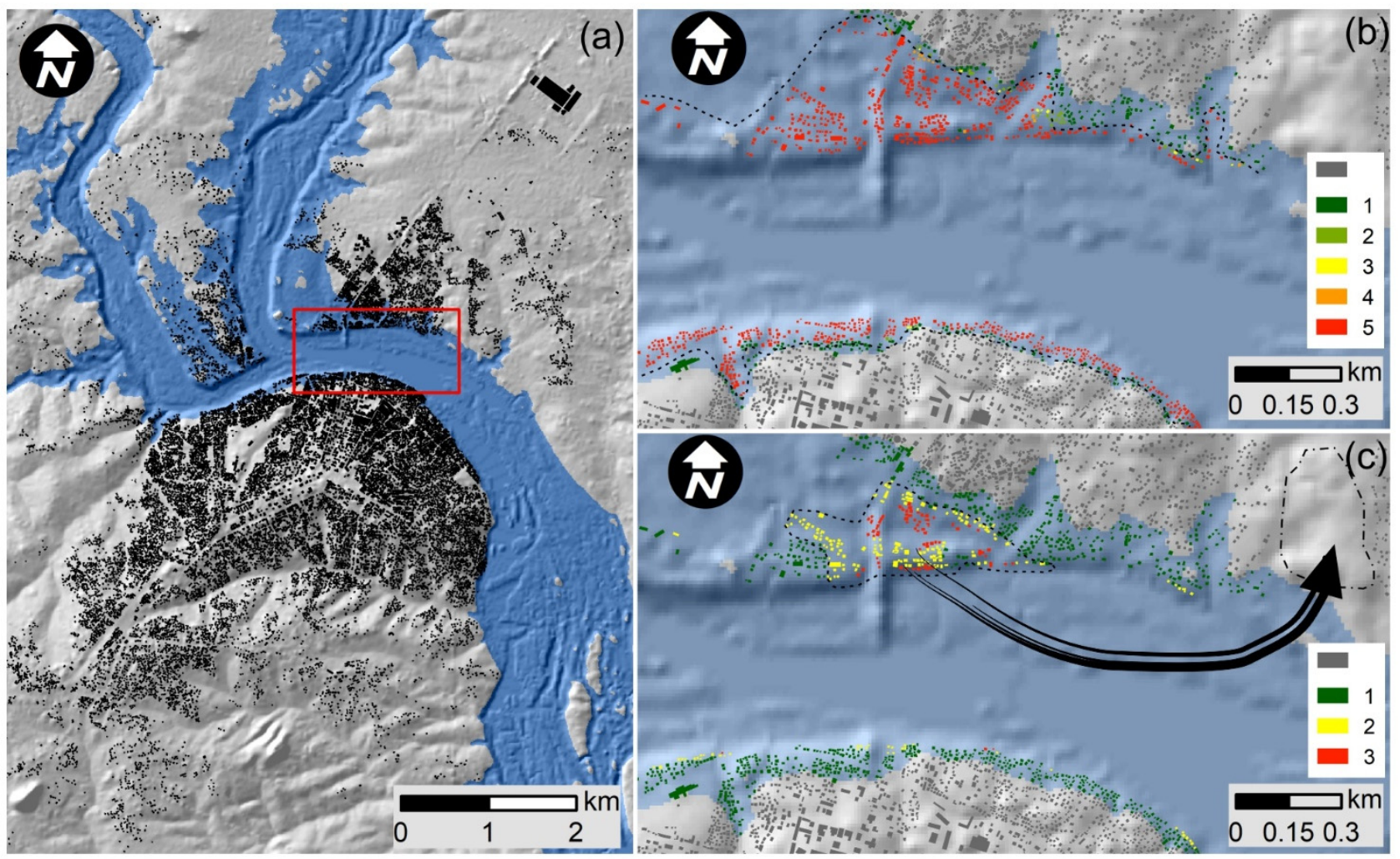

Figure 8. Spatial extent of the flooded area (a) for the January 2015 flooding event using the Copernicus DEM data. People dragging flood hazard analysis (b) using the Russo et al. [64] model (1 = low hazard for adults and children; 2 = low hazard for adults and high hazard for children; $3=$ moderate hazard for adults; 4 = significant hazard for adults; 5 = extreme hazard for adults). "Building stability for floods" hazard model (c) using the Pistrika and Jonkman [65] model (1 = inundation damage; 2 = partial damage; 3 = total destruction). The black dashed lines $(\mathbf{b}, \mathbf{c})$ show the demarcation of high hazard areas, while the black dash-dot lines and black arrow show the possible population rearrangement area from present results.

\section{Discussion}

The FFA results show the uncertainty associated to the distribution function used and the consideration in the analysis of only systematic or systematic + non-systematic data. Anyway, this is not one of the main objectives of the present assessment, but it shows the clear dependence of an accurate estimation of higher return periods on the presence of extreme events in the systematic records, or the use of non-systematic data (e.g., [68-70]). Thus, it is highly probable that the real return period for the January 2015 flooding event is lower than 500 years, because other known catastrophic events $(1970,2001,2013$, and 2019) may be underestimated in the peak flow record derived from the gauging station located in the city of Mocuba. The maximum peak flow for these other catastrophic events (except the 2019 event, which lies out of the temporal range of available time series) is only $4114 \mathrm{~m}^{3} \mathrm{~s}^{-1}$ in 1970, which is too far from the 13,000 to $18,000 \mathrm{~m}^{3} \mathrm{~s}^{-1}$ [51] estimate for the January 2015 event. Therefore, if we take into account that the extreme peak flow values may be underestimated (something that some Mozambican technicians already pointed out in personal communications), the frequency or return period associated with these extreme events must be significantly lower than that obtained in this FFA.

As regards hydraulic modelling, the results show the effect of DEM artefacts due to errors in topographic data. All these artefacts in the river channel could be partially removed by hydrological correction processes, which improve their suitability for simulating floods $[32,37,71]$ when compared with original DEMs due to the correct representation of the rivers and associated channels. However, no hydrological corrections have been carried 
out (beyond those previously carried out, and which are integrated in the data that can be downloaded from the web servers where each model is available) to maintain equal conditions for all DEM models, as neither Copernicus nor TanDEM-X show a clear need for hydrological corrections. On the contrary, in the case of the Copernicus model, the width of the Licungo River as it passes through the city of Mocuba allows for an efficient reproduction of the channel cross-section shape with the original spatial resolution of the DEM. This is another important factor to take into account in hydraulic modelling, which works with low spatial resolution DEMs, as previously pointed out by Sanders [6]. In fact, this may be a key point for future works involving Copernicus DEM, analyzing its ability to correctly reproduce the cross-section of narrower channels, and thus being able to produce useful results for flood hazard management in such scenarios.

With the aim to check the quality of the result of the hydraulic models, flow depth values were compared both with the Mocuba gauge station and with several field control points. Comparing the modelled flow depth values against the Mocuba gauge station rating curve involves uncertainty due to the characteristics of the gauge station itself. Probably, the most important factor is the Licungo riverbed mobility due to fluvial incision and deposition processes, which can produce variations over time in the flow depth-flow rate relationship for the gauging station [72]. The cross-sectional shape and elevation are critical parameters for a correct flow rate estimation, as well as in the determination of paleo-flow rates [73], and both parameters change over time due to erosional and depositional process associated to river dynamics. Thus, increases and decreases in flow velocity imply changes in the sediment transport capacity of water, which is directly related to the processes of fluvial erosion (linked to areas of higher flow velocity) and fluvial sedimentation (linked to areas of lower flow velocity, or when there is a decrease in flow velocity). All these variations occur during a river flood event and, as a consequence, cause variations in the shape of the channel cross-section, which are responsible (by modifying the drainage capacity of the channel) for altering the flow depth-flow rate relationship for that section of a river. Those changes are observed in the Mocuba gauge station record, so the rating curve was calculated by using only the more recent records (2000 to 2014), trying to avoid errors caused by older cross-sectional channel shapes that would have other associated flow depth-flow rate relationships. Using the more recent flow depth-flow rate data can limit the uncertainty linked to fluvial incision and deposition processes, but it can limit the availability of extreme event data; thus, a certain degree of uncertainty still remains.

Calibrating the results from flood models with water level data is usual for onedimensional (1D) simulation models [3,74-76], while 2D simulation models tend to be calibrated and validated by comparing extensional flooding areas [77,78]. In the present assessment, a 2D simulating model (Iber) was used for hydraulic modelling, but a calibrating of the model through flooding extension is not available due to the lack of observed (field) data or remote sensing data on the event date. Thus, we calibrated the performance of the models against a set of water level measurements $[9,15]$ in the study area.

Another way of calibrating hydraulic models is through the use of "citizen science", a calibration method that has been increasingly used since the 2010 decade. "citizen science" involves different types of data acquisition and a review of the "state of the art" could be found in Assumpção et al. [79]. Although most such cases are located in developed countries (e.g., [80,81]), some positive assessments have been carried out in developing countries too (e.g., [82,83]); as highlighted by the experience of Sy et al. [82], the use of "citizen science" could help reconstruct past flood events and open up an available path for obtaining useful flood data in areas of scarce or unavailable flow data records.

When flood hazard analysis was carried out in Mocuba city, the results from the two hazard models used [64,67] gave results that are in agreement with the field assistance works carried out by the International Federation of Red Cross and Red Crescent Societies [52]. However, some differences can by observed in the number of damaged buildings and damage levels. Building materials (masonry, bricks, woods, etc.) or types (elevated floor level, with or without a basement) cause significant changes in the damage rate 
associated with flow depth values, as can be seen in the compilation of Shrestha et al. [84]. Thus, the quantitative results of the damage model should be viewed with caution, and it is likely that they should be used through a more qualitative approach.

Finally, the results obtained for Mocuba city could be of help to local natural hazard managers, the Zambezia regional government, or the Mozambican government with land planning and flood risk management and mitigation. Thus, the number, location, and spatial distribution of buildings at high flood hazard (Figure 8c) could help design plans for the relocation of the population at risk of flooding to other, less hazardous areas of the city.

\section{Conclusions}

The city of Mocuba (Mozambique) has been selected to perform an assessment of free global DEMs and hydrodynamic modelling for flood hazard analysis. The choice of Mocuba city was due upon two main criteria: the city belongs to a developing country (where the availability of high-resolution DEMs is practically nil) and there is a repeated occurrence of flood events (the one that occurred during the month of January 2015 being that with the highest recorded magnitude).

The visual and statistical analysis of results from hydrodynamic models (for each of the eight DEMs) highlights the improved performance of the Copernicus DEM, the most recent of all DEMs used. Thus, a visual analysis of flow depth parameters shows more natural trends in its spatial variability, which could be related to the presence of riff and pools in the riverbed. This trend of results is less evident for TanDEM-X and MERIT DEMs, and it is totally unrecognizable for the rest of the models, where the variations in flow depth cannot be due to the natural forms of the channel but to the presence of topographic errors.

The statistical analysis of results through the use of MAE and NSE indexes point to the same conclusions. The performance of the Copernicus DEM is an improvement over all the other ones, and this free global DEM is the only one where the flow depth value in all the selected non-flooding control points was equal to $0.00 \mathrm{~m}$. The results shown by the Copernicus DEM against field data (Mocuba gauge station and field control points) are much better than with any other free global DEMs.

The hydraulic model (using the Copernicus DEM) outputs, such as flow depth and flow velocity, have made it possible to define different flood hazard areas in Mocuba city. The use of the dragging people flood hazard model as well as building structural stability models have shown results (number of buildings at high hazard levels) that are in agreement with previous reports, such as that of the International Federation of Red Cross and Red Crescent Societies.

There are multiple previous research papers that advocate the need to improve the quality of the free global DEMs in order to develop more reliable flood hazard maps. Most of these previous studies do not use the last version of the Copernicus DEM, because it was launched barely more than a year ago. However, in view of the results obtained in the present study, the use of the Copernicus DEM along with flooding evidence field data could be a reliable approach to flood hazard assessment in developing countries, or at least for those rivers whose dimensions (river width) allow for an acceptable reproduction of their shape with the spatial resolution of these free global DEMs. Anyway, the results obtained should not be interpreted as an amendment to two widely agreed upon proposals: the need to improve the spatial resolution and quality of the global models, and the need to promote citizen participation in the collection of field data to improve the calibration of hydraulic models for flood hazard analysis.

Funding: This research received no external funding.

Data Availability Statement: Data available on request due to the size of hydraulic models output.

Acknowledgments: The author wants to acknowledge the "Universidade Pedagógica de Mozambique" for their support in the Mocuba field campaign, and especially the MSc. The authors thanks Hélio Vasco Nganhane for his support in collecting the field data and hydro-meteorological data used in this study. 
Conflicts of Interest: The authors declare no conflict of interest.

\section{Appendix A}

The different free global DEMs used in the present assessment can be downloaded from the following web pages:

- Alos Palsar DEM: https:// search.earthdata.nasa.gov / search; Platforms = ALOS.

- $\quad$ ASTER DEM: https:// search.earthdata.nasa.gov / search; Instruments = ASTER.

- Bare Earth DEM: http://data.bris.ac.uk/data/dataset/10tv0p32gizt01nh9edcjzd6wa.

- $\quad$ SRTM DEM: https://search.earthdata.nasa.gov / search; Instruments = SRTM.

- MERIT DEM: http://hydro.iis.u-tokyo.ac.jp/yamadai/MERIT_DEM/.

- TanDEM-X DEM: https://download.geoservice.dlr.de/TDM90/.

- NASADEM: https://search.earthdata.nasa.gov/search?q=C1546314436-LPDAAC_ECS.

- Copernicus DEM: https://portal.opentopography.org/raster?opentopoID=OTSDEM. 032021.4326.3.

At the same time, other free data sources were used in the present assessment:

- OpenStreetMap: https://www.openstreetmap.org/\#map=17/-16.82757/36.98902.

\section{References}

1. CRED. The International Disaster Database [online], Centre for Research on the Epidemiology of Disasters. Available online: https:/ / public.emdat.be (accessed on 22 July 2021).

2. Hallegatte, S.; Green, C.; Nicholls, R.J.; Corfee-Morlot, J. Future flood losses in major coastal cities. Nat. Clim. Chang. 2013, 3, 802-806. [CrossRef]

3. Horritt, M.; Bates, P. Evaluation of 1D and 2D numerical models for predicting river flood inundation. J. Hydrol. 2002, 268, 87-99. [CrossRef]

4. Horritt, M.; Bates, P. Effects of spatial resolution on a raster based model of flood flow. J. Hydrol. 2001, 253, 239-249. [CrossRef]

5. Casas, A.; Benito, G.; Thorndycraft, V.; Rico, M. The topographic data source of digital terrain models as a key element in the accuracy of hydraulic flood modelling. Earth Surf. Process. Landf. 2006, 31, 444-456. [CrossRef]

6. Sanders, B.F. Evaluation of on-line DEMs for flood inundation modeling. Adv. Water Resour. 2007, 30, 1831-1843. [CrossRef]

7. Saksena, S.; Merwade, V. Incorporating the effect of DEM resolution and accuracy for improved flood inundation mapping. J. Hydrol. 2015, 530, 180-194. [CrossRef]

8. Savage, J.T.S.; Bates, P.; Freer, J.; Neal, J.; Aronica, G. When does spatial resolution become spurious in probabilistic flood inundation predictions? Hydrol. Process. 2016, 30, 2014-2032. [CrossRef]

9. Savage, J.T.S.; Pianosi, F.; Bates, P.; Freer, J.; Wagener, T. Quantifying the importance of spatial resolution and other factors through global sensitivity analysis of a flood inundation model. Water Resour. Res. 2016, 52, 9146-9163. [CrossRef]

10. Boettle, M.; Kropp, J.; Reiber, L.; Roithmeier, O.; Rybski, D.; Walther, C. About the influence of elevation model quality and small-scale damage functions on flood damage estimation. Nat. Hazards Earth Syst. Sci. 2011, 11, 3327-3334. [CrossRef]

11. Arrighi, C.; Campo, L. Effects of digital terrain model uncertainties on high-resolution urban flood damage assessment. J. Flood Risk Manag. 2019, 12, 12530. [CrossRef]

12. Bhuyian, M.N.; Kalyanapu, A. Accounting digital elevation uncertainty for flood consequence assessment. J. Flood Risk Manag. 2017, 11, S1051-S1062. [CrossRef]

13. Fewtrell, T.J.; Bates, P.D.; Horritt, M.; Hunter, N.M. Evaluating the effect of scale in flood inundation modelling in urban environments. Hydrol. Process. 2008, 22, 5107-5118. [CrossRef]

14. Bermúdez, M.; Zischg, A.P. Sensitivity of flood loss estimates to building representation and flow depth attribution methods in micro-scale flood modelling. Nat. Hazards 2018, 92, 1633-1648. [CrossRef]

15. Neal, J.C.; Bates, P.; Fewtrell, T.J.; Hunter, N.M.; Wilson, M.; Horritt, M.S. Distributed whole city water level measurements from the Carlisle 2005 urban flood event and comparison with hydraulic model simulations. J. Hydrol. 2009, 368, 42-55. [CrossRef]

16. Hai, P.T.; Magome, J.; Yorozuya, A.; Inomata, H.; Fukami, K.; Takeuchi, K. Large-scale flooding analysis in the suburbs of Tokyo Metropolis caused by levee breach of the Tone River using a 2D hydrodynamic model. Water Sci. Technol. 2010, 62, 1859-1864. [CrossRef]

17. Chen, A.; Evans, B.; Djordjevic, S.; Savic, D. Multi-layered coarse grid modelling in 2D urban flood simulations. J. Hydrol. 2012, 470-471, 1-11. [CrossRef]

18. Meesuk, V.; Vojinovic, Z.; Mynett, A.E.; Abdullah, A.F. Urban flood modelling combining top-view LiDAR data with ground-view SfM observations. Adv. Water Resour. 2015, 75, 105-117. [CrossRef]

19. Hawker, L.; Bates, P.; Neal, J.; Rougier, J. Perspectives on Digital Elevation Model (DEM) Simulation for Flood Modeling in the Absence of a High-Accuracy Open Access Global DEM. Front. Earth Sci. 2018, 6, 233. [CrossRef] 
20. Wise, S. Assessing the quality for hydrological applications of digital elevation models derived from contours. Hydrol. Process. 2000, 14, 1909-1929. [CrossRef]

21. Bater, C.W.; Coops, N.C. Evaluating error associated with lidar-derived DEM interpolation. Comput. Geosci. 2009, 35, $289-300$. [CrossRef]

22. Guo, Q.; Li, W.; Yu, H.; Alvarez, O. Effects of Topographic Variability and Lidar Sampling Density on Several DEM Interpolation Methods. Photogramm. Eng. Remote Sens. 2010, 76, 701-712. [CrossRef]

23. Manson, S.M.; Burrough, P.A.; McDonnell, R.A. Principles of Geographical Information Systems; Oxford University Press: Oxford, UK, 1998.

24. Woodrow, K.; Lindsay, J.B.; Berg, A.A. Evaluating DEM conditioning techniques, elevation source data, and grid resolution for field-scale hydrological parameter extraction. J. Hydrol. 2016, 540, 1022-1029. [CrossRef]

25. Gamba, P.; Dell Acqua, F.; Houshmand, B. SRTM data characterization in urban areas. Int. Arch. Photogramm. Remote Sens. Spat. Inf. Sci. 2002, 34, 55-58.

26. Farr, T.G.; Rosen, P.A.; Caro, E.; Crippen, R.; Duren, R.; Hensley, S.; Kobrick, M.; Paller, M.; Rodriguez, E.; Roth, L.; et al. The Shuttle Radar Topography Mission. Rev. Geophys. 2007, 45, 1-33. [CrossRef]

27. Carabajal, C.C.; Harding, D.J. SRTM C-Band and ICESat Laser Altimetry Elevation Comparisons as a Function of Tree Cover and Relief. Photogramm. Eng. Remote Sens. 2006, 72, 287-298. [CrossRef]

28. LaLonde, T.; Shortridge, A.; Messina, J. The Influence of Land Cover on Shuttle Radar Topography Mission (SRTM) Elevations in Low-relief Areas. Trans. GIS 2010, 14, 461-479. [CrossRef]

29. Yan, K.; Tarpanelli, A.; Balint, G.; Moramarco, T.; Di Baldassarre, G. Exploring the Potential of SRTM Topography and Radar Altimetry to Support Flood Propagation Modeling: Danube Case Study. J. Hydrol. Eng. 2015, 20, 04014048. [CrossRef]

30. Sampson, C.C.; Smith, A.M.; Bates, P.; Neal, J.; Trigg, M. Perspectives on Open Access High Resolution Digital Elevation Models to Produce Global Flood Hazard Layers. Front. Earth Sci. 2016, 3, 85. [CrossRef]

31. Li, J.; Wong, D.W. Effects of DEM sources on hydrologic applications. Comput. Environ. Urban Syst. 2010, 34, 251-261. [CrossRef]

32. Jarihani, A.A.; Callow, J.; McVicar, T.; Van Niel, T.G.; Larsen, J. Satellite-derived Digital Elevation Model (DEM) selection, preparation and correction for hydrodynamic modelling in large, low-gradient and data-sparse catchments. J. Hydrol. 2015, 524, 489-506. [CrossRef]

33. /Yamazaki, D.; Ikeshima, D.; Tawatari, R.; Yamaguchi, T.; O’Loughlin, F.; Neal, J.C.; Sampson, C.C.; Kanae, S.; Bates, P.B. A high-accuracy map of global terrain elevations. Geophys. Res. Lett. 2017, 44, 5844-5853. [CrossRef]

34. Chen, H.; Liang, Q.; Liu, Y.; Xie, S. Hydraulic correction method (HCM) to enhance the efficiency of SRTM DEM in flood modeling. J. Hydrol. 2018, 559, 56-70. [CrossRef]

35. Hirt, C. Artefact detection in global digital elevation models (DEMs): The Maximum Slope Approach and its application for complete screening of the SRTM v4.1 and MERIT DEMs. Remote Sens. Environ. 2018, 207, 27-41. [CrossRef]

36. Álvarez, M.; Puertas, J.; Peña, E.; Bermúdez, M. Two-Dimensional Dam-Break Flood Analysis in Data-Scarce Regions: The Case Study of Chipembe Dam, Mozambique. Water 2017, 9, 432. [CrossRef]

37. Archer, L.; Neal, J.C.; Bates, P.D.; House, J. Comparing TanDEM-X Data With Frequently Used DEMs for Flood Inundation Modeling. Water Resour. Res. 2018, 54, 205-222. [CrossRef]

38. Massazza, G.; Tamagnone, P.; Wilcox, C.; Belcore, E.; Pezzoli, A.; Vischel, T.; Panthou, G.; Ibrahim, M.H.; Tiepolo, M.; Tarchiani, V.; et al. Flood Hazard Scenarios of the Sirba River (Niger): Evaluation of the Hazard Thresholds and Flooding Areas. Water 2019, 11, 1018. [CrossRef]

39. Muthusamy, M.; Casado, M.R.; Butler, D.; Leinster, P. Understanding the effects of Digital Elevation Model resolution in urban fluvial flood modelling. J. Hydrol. 2021, 596, 126088. [CrossRef]

40. Wang, W.; Yang, X.; Yao, T. Evaluation of ASTER GDEM and SRTM and their suitability in hydraulic modelling of a glacial lake outburst flood in southeast Tibet. Hydrol. Process. 2012, 26, 213-225. [CrossRef]

41. Utlu, M.; Özdemir, H. How much spatial resolution do we need to model a local flood event? Benchmark testing based on UAV data from Biga River (Turkey). Arab. J. Geosci. 2020, 13, 1-14. [CrossRef]

42. Da Costa, R.T.; Mazzoli, P.; Bagli, S. Limitations Posed by Free DEMs in Watershed Studies: The Case of River Tanaro in Italy. Front. Earth Sci. 2019, 7, 141. [CrossRef]

43. Sampson, C.C.; Smith, A.M.; Bates, P.; Neal, J.; Alfieri, L.; Freer, J. A high-resolution global flood hazard model. Water Resour. Res. 2015, 51, 7358-7381. [CrossRef]

44. Alfieri, L.; Salamon, P.; Bianchi, A.; Neal, J.; Bates, P.; Feyen, L. Advances in pan-European flood hazard mapping. Hydrol. Process. 2014, 28, 4067-4077. [CrossRef]

45. Dottori, F.; Salamon, P.; Bianchi, A.; Alfieri, L.; A Hirpa, F.; Feyen, L. Development and evaluation of a framework for global flood hazard mapping. Adv. Water Resour. 2016, 94, 87-102. [CrossRef]

46. Simpson, A.L.; Balog, S.A.B.; Moller, D.K.; Strauss, B.H.; Saito, K. An urgent case for higher resolution digital elevation models in the world's poorest and most vulnerable countries. Front. Earth Sci. 2015, 3, 50. [CrossRef]

47. Schumann, G.J.-P.; Bates, P.D. Editorial: The Need for a High-Accuracy, Open-Access Global Digital Elevation Model. Front. Earth Sci. 2020, 8, 618194. [CrossRef]

48. Bladé, E.; Cea, L.; Corestein, G.; Escolano, E.; Puertas, J.; Vázquez-Cendón, E.; Dolz, J.; Coll, A. Iber: Herramienta de simulación numérica del flujo en ríos. Rev. Int. Métodos Numéricos Cálculos Diseño Ing. 2014, 30, 1-10. [CrossRef] 
49. Huizinga, J.; De Moel, H.; Szewczyk, W. Global Flood Depth-Damage Functions: Methodology and the Database with Guidelines; Joint Research Centre: Luxembourg, 2017; p. 114. [CrossRef]

50. Dutch Risk Reduction Team. Flood Control in the Licungo Basin of Zambezi Province; Dutch Government: Amsterdam, The Netherlands, 2015; p. 85.

51. The World Bank, United Nations and European Union. Mozambique: Damage Assessment, and Early Recovery and Sustainable Reconstruction Priorities; ACP-EU Natural Disaster Risk Reduction Program: Brussels, Belgium, 2017 ; p. 108.

52. Spanish Red Cross and Danish Red Cross. Emergency Appeal Final Report-Mozambique: Floods; International Federation of Red Cross and Red Crescent Societies: Geneva, Switzerland, 2016; p. 22.

53. Tadono, T.; Ishida, H.; Oda, F.; Naito, S.; Minakawa, K.; Iwamoto, H. Precise Global DEM Generation by ALOS PRISM. ISPRS Ann. Photogramm. Remote Sens. Spat. Inf. Sci. 2014, II-4, 71-76. [CrossRef]

54. Meyer, D.J.; Tachikawa, T.; Abrams, M.; Crippen, R.; Krieger, T.; Gesch, D.; Carabajal, C. Summary of the validation of the second version of the ASTER GDEM. ISPRS-Int. Arch. Photogramm. Remote Sens. Spat. Inf. Sci. 2012, 39, 291-293. [CrossRef]

55. O'Loughlin, F.; Paiva, R.; Durand, M.; Alsdorf, D.; Bates, P. A multi-sensor approach towards a global vegetation corrected SRTM DEM product. Remote Sens. Environ. 2016, 182, 49-59. [CrossRef]

56. Wessel, B.; Huber, M.; Wohlfart, C.; Marschalk, U.; Kosmann, D.; Roth, A. Accuracy assessment of the global TanDEM-X Digital Elevation Model with GPS data. ISPRS J. Photogramm. Remote Sens. 2018, 139, 171-182. [CrossRef]

57. Buckley, S.M.; Agram, P.S.; Belz, J.E.; Crippen, R.E.; Gurrola, E.M.; Hensley, S.; Kobrick, M.; Lavalle, M.; Martin, J.M.; Neumann, M.; et al. NASADEM User Guide v1; National Aeronautics and Space Administration: Washington, DC, USA, 2020.

58. Fahrland, E. Copernicus Digital Elevation Model. In Product Handbook; Airbus Defence and Space GmbH: Potsdam, Germany, 2020.

59. Rizzoli, P.; Martone, M.; Gonzalez, C.; Wecklich, C.; Tridon, D.B.; Bräutigam, B.; Bachmann, M.; Schulze, D.; Fritz, T.; Huber, M.; et al. Generation and performance assessment of the global TanDEM-X digital elevation model. ISPRS J. Photogramm. Remote Sens. 2017, 132, 119-139. [CrossRef]

60. OpenStreetMap Contributors: OpenStreetMap. Available online: https://www.openstreetmap.org/copyright (accessed on 3 August 2021)

61. Hecht, R.; Kunze, C.; Hahmann, S. Measuring Completeness of Building Footprints in OpenStreetMap over Space and Time. ISPRS Int. J. Geo-Inf. 2013, 2, 1066-1091. [CrossRef]

62. Barrington-Leigh, C.; Millard-Ball, A. The world's user-generated road map is more than $80 \%$ complete. PLoS ONE 2017, 12, e0180698. [CrossRef]

63. Cerri, M.; Steinhausen, M.; Kreibich, H.; Schröter, K. Are OpenStreetMap building data useful for flood vulnerability modelling? Nat. Hazards Earth Syst. Sci. 2021, 21, 643-662. [CrossRef]

64. Russo, B.; Gómez, M.; Macchione, F. Pedestrian hazard criteria for flooded urban areas. Nat. Hazards 2013, 69, 251-265. [CrossRef]

65. Koutsoyiannis, D. A critical review of probability of extreme rainfall: Principles and models. In Advances in Urban Flood Management; Ashley, R., Garvin, S., Pasche, E., Vassilopoulos, A., Zevenbergen, C., Eds.; Taylor \& Francis: London, UK, 2007; pp. 139-166. [CrossRef]

66. Moccia, B.; Mineo, C.; Ridolfi, E.; Russo, F.; Napolitano, F. Probability distributions of daily rainfall extremes in Lazio and Sicily, Italy, and design rainfall inferences. J. Hydrol. Reg. Stud. 2021, 33, 100771. [CrossRef]

67. Pistrika, A.K.; Jonkman, S.N. Damage to residential buildings due to flooding of New Orleans after hurricane Katrina. Nat. Hazards 2010, 54, 413-434. [CrossRef]

68. Stedinger, J.R.; Griffis, V.W. Flood Frequency Analysis in the United States: Time to Update. J. Hydrol. Eng. 2008, 13, 199-204. [CrossRef]

69. Botero, B.A.; Francés, F. Estimation of high return period flood quantiles using additional non-systematic information with upper bounded statistical models. Hydrol. Earth Syst. Sci. 2010, 14, 2617-2628. [CrossRef]

70. Beneyto, C.; Aranda, J.Á.; Benito, G.; Francés, F. New Approach to Estimate Extreme Flooding Using Continuous Synthetic Simulation Supported by Regional Precipitation and Non-Systematic Flood Data. Water 2020, 12, 3174. [CrossRef]

71. Farooq, M.; Shafique, M.; Khattak, M.S. Flood hazard assessment and mapping of River Swat using HEC-RAS 2D model and high-resolution 12-m TanDEM-X DEM (WorldDEM). Nat. Hazards 2019, 97, 477-492. [CrossRef]

72. Rojas, M.; Quintero, F.; Young, N. Analysis of Stage-Discharge Relationship Stability Based on Historical Ratings. Hydrology 2020, 7, 31. [CrossRef]

73. Machado, M.; Medialdea, A.; Calle, M.; Rico, M.; Sánchez-Moya, Y.; Sopeña, A.; Benito, G. Historical palaeohydrology and landscape resilience of a Mediterranean rambla (Castellón, NE Spain): Floods and people. Quat. Sci. Rev. 2017, 171, 182-198. [CrossRef]

74. Pappenberger, F.; Beven, K.; Horritt, M.; Blazkova, S. Uncertainty in the calibration of effective roughness parameters in HEC-RAS using inundation and downstream level observations. J. Hydrol. 2005, 302, 46-69. [CrossRef]

75. Mark, O.; Weesakul, S.; Apirumanekul, C.; Aroonnet, S.B.; Djordjević, S. Potential and limitations of 1D modelling of urban flooding. J. Hydrol. 2004, 299, 284-299. [CrossRef]

76. Felder, G.; Zischg, A.P.; Weingartner, R. The effect of coupling hydrologic and hydrodynamic models on probable maximum flood estimation. J. Hydrol. 2017, 550, 157-165. [CrossRef] 
77. Pappenberger, F.; Frodsham, K.; Beven, K.; Romanowicz, R.; Matgen, P. Fuzzy set approach to calibrating distributed flood inundation models using remote sensing observations. Hydrol. Earth Syst. Sci. 2007, 11, 739-752. [CrossRef]

78. Tarpanelli, A.; Brocca, L.; Melone, F.; Moramarco, T. Hydraulic modelling calibration in small rivers by using coarse resolution synthetic aperture radar imagery. Hydrol. Process. 2013, 27, 1321-1330. [CrossRef]

79. Assumpção, T.H.; Popescu, I.; Jonoski, A.; Solomatine, D.P. Citizen observations contributing to flood modelling: Opportunities and challenges. Hydrol. Earth Syst. Sci. 2018, 22, 1473-1489. [CrossRef]

80. Fohringer, J.; Dransch, D.; Kreibich, H.; Schröter, K. Social media as an information source for rapid flood inundation mapping. Nat. Hazards Earth Syst. Sci. 2015, 15, 2725-2738. [CrossRef]

81. Smith, L.S.; Liang, Q.; James, P.; Lin, W. Assessing the utility of social media as a data source for flood risk management using a real-time modelling framework. J. Flood Risk Manag. 2015, 10, 370-380. [CrossRef]

82. Sy, B.; Frischknecht, C.; Dao, H.; Consuegra, D.; Giuliani, G. Reconstituting past flood events: The contribution of citizen science. Hydrol. Earth Syst. Sci. 2020, 24, 61-74. [CrossRef]

83. Walker, D.; Forsythe, N.; Parkin, G.; Gowing, J. Filling the observational void: Scientific value and quantitative validation of hydrometeorological data from a community-based monitoring programme. J. Hydrol. 2016, 538, 713-725. [CrossRef]

84. Shrestha, B.B.; Kawasaki, A.; Zin, W.W. Development of flood damage assessment method for residential areas considering various house types for Bago Region of Myanmar. Int. J. Disaster Risk Reduct. 2021, 66, 102602. [CrossRef] 